\title{
PENGUNGKAPAN GAGASAN-GAGASAN TENTANG KETIDAKADILAN GENDER DALAM NOVEL GENI JORA
}

\author{
(Ida Farida Sachmadi, Sapardi Djoko Damono, Harfiyah Widiawati) \\ Fakultas Ilmu Budaya Universitas Padjadjaran \\ E-mail : idasachmadi@yahoo.co.id
}

\begin{abstract}
ABSTRAK Kajian ini meneliti cara gagasan-gagasan diungkapkan dalam novel Geni Jora karya Abidah EL Khalieqy berdasarkan teori yang disusun Raymond Williams. Teori tersebut mengatakan bahwa ada tujuh tipe cara gagasan-gagasan diungkapkan dalam sebuah karya fiksi: 1) mempropagandakannya; 2) menambahkan gagasan; 3) memperbantahkan gagasan; 4) menyodorkan gagasan sebagai konvensi; 5) memunculkan gagasan melalui penokohan; 6) melarutkan gagasan dalam cerita; 7) menampilkannya sebagai suprstruktur. Gagasan yang diteliti hanyalah yang berbicara mengenai ketidakadilan gender, yang didasarkan pada pandangan feminis muslim seperti pandangan Nasaruddin Umar, Anita Rahman, Fatima Mernissi, dan Ali Ashgar Engineer, karena tujuan dari penelitian ini adalah menunjukkan dengan tipe apa teks menyampaikan gagasan-gagasan mengenai ketidakadilan gender. Gagasan-gagasan tersebut dianalisis dengan cara mengkaji unsur-unsur naratif tertentu dari teori Gérard Genette dan Seymour Chatman, yaitu peristiwa, alur, penokohan, dan sudut pandang, selain suara naratif untuk melihat keberpihakan tkes. Hasil penelitian menunjukkan bahwa novel Geni Jora menggunakan tipe kedua yaitu penambahan gagasan pada cerita dan tipe kelima yaitu memunculkan gagasan melalui penokohan. Selain itu, analisis suara naratif memperlihatkan bahwa novel ini sangat berpihak pada perempuan.
\end{abstract}

Kata kunci: tujuh tipe pengungkapan gagasan teori Raymond Williams, ketidakadilan gender, unsur naratif, Geni Jora.

\section{DISCLOSURE OF IDEAS ABOUT GENDER INJUSTICE THE NOVEL GENI JORA}

ABSTRACT This study examines the ways ideas are expressed in Abidah El Khalieqy's novel Geni Jora, based on Raymond Williams' theory, which says that there are seven types of expressing ideas: 1) propagating; 2) embodying; 3) arguing; 4) showing ideas as a convention; 5) espressing ideas as characters; 6) dissolving ideas into the whole fictional world;7) performing ideas as a superstructure. The ideas analysed are only the ones talking about gender inequities, which are based on the views of some muslim feminists, such as Nasaruddin Umar, Anita Rahman, Fatima Mernissi, and Ali Ashgar Engineer. These ideas are analysed by using certain narrative elements from the theory of Gerrard Genette and Seymour Chatman: events, plot, characterization, and point of view, besides the narrative voice to see the inclination of the text. This research has shown that Geni Jora uses the second type, that is emboying the ideas, and the fifth type, that is expressing ideas as characters. Besides that, the analysis of the narrative voice implies that this novel inclines heavily to women.

Key words: Raymond Williams' theory of seven types in expressing ideas, gender inequities, narrative elements, Geni Jora.

\section{PENDAHULUAN}

Dari lima novel Abidah El Khalieqy, satu telah mendapat penghargaan dariDewan Kesenian Jakarta sebagai pemenang satu Lomba Penulisan Novel Dewan Kesenian Jakarta 2003. Telah banyak skripsi dan tesis yang menganalisis novel tersebut dan semuanya membahas nuansa feminisme yang terkandung di dalamnya. Adalah lain yang menarik dari karya ini, yaitu cara gagasan-gagasan tentang feminisme atau lebih tepat tentang ketidakadilan gender diungkapkan dalam novel tersebut.

Untuk melihat bagaimana gagasan-gagasan tentang ketidakadilan gender diungkapkan dalam novel, digunakan teori yang disusun oleh Raymond Williams, seorang kritikus sastra dari Inggris. Gagasan-gagasan ini diperoleh dari analisis unsur-unsur sastra, terutama diperoleh dari hasil analisis; simpulan analisis novel ini akan menunjukkan suara keberpihakan teks. Unsur-unsur intrinsik yang digunakan mengacu kepada Seymour Chatman. Gagasan-gagasan yang dianalisis mirip dengan pandangan para feminis muslim mengenai ketidakadilan gender, khususnya Nasaruddin Umar, Anita Rahman, Fatima Memissi, and Ali Ashgar Engineer.
Dalam esainya yang berjudul "Dickens and Social Ideas" dalambukuSociology OfLiterature\&Drama(1973) yang diedit Elizabeth and Tom Burns, Williams meneliti tentang gagasan (idea) dan sikap (attitude) teks terhadap gagasan di dalarnnya dan menjelaskan hubunganhubungan yang ada antara karya sastra dan gagasan. Ia menyebutkan tujuh macam cara yang dapat digunakan untuk mengekspresikan gagasan-gagasan ke dalam novel, yaitu (1) mempropagandakannya; (2) menambahkan gagasan ke dalamnya; (3) memperbantahkan gagasan; (4) menyodorkan gagasan sebagai konvensi; (5) memunculkan gagasan melalui penokohan; (6) melarutkan gagasan dalam cerita, dan (7) menampilkannya sebagai super struktur. (2002: 18).

Gagasan mengenai ketidakadilan gender yang diungkapkan dalam novel yang diteliti berterima dengan gagasan feminisme. Gagasan tersebut sesuai dengan pendapat dua feminis muslim ketika membahas kedudukan dan hak-hak perempuan dalam keluarga. Salah satunya adalah Nasaruddin Umar, yang dalam bukunya berjudul Argumentasi Kesetaraan Jender (1999) secara global menguraikan kedudukan perempuan menurut Alquran. Selain itu, dipakai juga bahasan Anita Rahman yang dalam esainya "Women in the Family: Reinterpretation by Muslim Feminists" 
(2005) yang membahas hak-hak perempuan dalam rumah tangga berdasarkan Alquran. Juga diambil konsep keadilan gender dari Asghar Ali Engineer dan Fatima Mernissi. Kedudukan perempuan yang dimaksud adalah pembagian tanggung-jawab dan peran yang adil, sedangkan hak-hak perempuan yang akan dicari dalam dua novel El Khalieqy adalah hak perlakuan setara antara laki-laki dan perempuan dan hak terbebas dari kekerasan dan pemaksaan.

Gagasan-gagasan dalam novel telah didapatkan dari analisis struktur tentang penokohan, alur, dan penguraian sudut pandang para tokoh utama. Menurut Chatman, dalam bukunya Story and Discourse (1978), tokoh bukanlah orang (person) yang mempunyai kepribadian (personality) melainkan hanya sekumpulan sifat (paradigm of traits) (1978: 111). Sifat-sifat tokoh diperoleh dari karakterisasi yang digambarkan penulis mengenaikarakter tokohmelalui penampilanfisik, tingkah laku, dan pandangan hidupnya. Alur (events) dibutuhkan karena merupakan alat pendukung bagi pembaca untuk menangkap penggambaran para tokoh dalam mengalami dan menjalani berbagai hal yang terjadi. Dari alur, pembaca juga dapat menangkap gagasan utama yang tersembunyi dalam teks. Sudut pandang dicari karena ia sangat mendukung pemerolehan gagasan-gagasan. Sudut pandang dimiliki oleh penutur dan semua tokoh dalam teks yang menyampaikan pemikirannya baik lisan atau hanya dalam pikiran(1978: 153).

\section{METODE}

Penelitian ini menggunakan metode deskriptif analitis. Penulis melakukan penelitian ini dengan beberapa tahapan. Tahap pertama dicari gagasangagasan tentang ketidakadilan gender dalam novel yang diteliti, yang didasarkan pada teori beberapa feminis muslim, terutama melalui penarasian peristiwa dan pengaturan peristiwa-peristiwa. Jalur cerita dari novel yang diteliti, yang sangat didukung dengan penelaahan sudut pandang tokoh-tokoh utamanya dengan menggunakan teori struktur yang disusun oleh Seymour Chatman. Telah dilakukan juga analisis penokohan tokoh utama sebagai pendukung penelitian di atas, selain analisis suara naratif untuk melihat sikap teks terhadap gagasan-gagasan yang muncul. Pada tahap berikutnya, dianalisis bagaimana gagasangagasan tersebut diwujudkan dalam novel dengan teori Raymond Williams sebagai acuannya.

\section{HASIL DAN PEMBAHASAN}

Gagasan yang muncul dari isu kesetaraan gender adalah gagasan tentang kesetaraan dalam memperoleh pendidikan dan pengetahuan, dalam mengekspresikan hasrat cinta, dalam mendapatkan kemerdekaan bertindak, dalam mencurahkan pikiran dan emosi, dalam memiliki jumlah partner (suami/istri), dalam memeroleh kesetaraan itu sendiri, dan dalam mendapatkan cinta dari lawan jenis.

Sebelum meneliti isi sudut pandang dan aksi-aksi tokoh utama untuk mendapatkan gagasan dalam isu kesetaraan gender, terlebih dahulu akan diuraikan penokohan dua tokoh utama, yaitu Kejora dan Zakky Hedouri.
Kejora disebutkan berasal dari keluarga keturunan Arab yang tinggal di sebuah desa di Jawa Timur. Dia cantik dan cerdas. Temannya di pesantren pemah berkomentar tentang kecantikannya: “ ... Wong samasama [Kejora dan Elya] cantik ... “ (98). Zakky Hedouri memujanya: "Mukminat yang hanif, cerdas, tahu bersyukur pada Tuhan dan luar biasa cantik." (140). Zakky adalah pemuda tampan keturunan Arab dan Turki (148). Diajuga cerdas dengan banyak mengisi seminar-seminar ketika ia masih mahasiswa S2(130).

Ada tiga alur cerita dalam novel ini. Yang pertama adalah alur cerita dengan waktu penceritaan masa kini, yaitu cerita tentang Kejora dan pacamya, Zakky Hedouri. Kedua adalah alur cerita dengan waktu cerita masa lalu saat Kejora bersekolah di pesantren putri, yaitu cerita tentang Kejora dan sahabatnya, Elya Huraibi. Terakhir, alur cerita dengan waktu cerita mundur lagi ke masa kanak-kanak Kejora, yaitu cerita antara Kejora dan neneknya.

Gagasan kesetaraan gender yang dituntut oleh penutur, yangjuga tokoh utama ini, muncul karena perlakuan tak setara yang ia alami saat ia masih kanak-kanak. Karenanya, pembahasan akan dimulai dari alur cerita Kejora dan neneknya. Sejak kecil, nenek Kejora selalu memenangkan laki-laki:

“. .. . Dari atas kursinya, nenekku mulai ceramah. Bahwa perempuan harus selalu mau mengalah. Jika perempuan tidak mau mengalah, dunia ini akan jungkir-balik berantakan seperti pecahan kaca. Sebab tidak ada laki-laki yang mau mengalah. Laki-laki selalu ingin menang dan menguasai kemenangan. Sebab itu perempuan harus siap me-nga-lah (pakai awalan 'me'). (El Khalieqy, 2004: 61)

Sudut pandang Nenek adalah suara yang sedang dilawan Kejora. Kutipan di atas dengan sangat eksplisit menunjukkan bahwa posisi laki-laki dalam kehidupan lebih tinggi daripada perempuan. Alasan sang nenek sangat sederhana: karena laki-laki selalu ingin menang. Kata 'ingin' menunjukkan bahwa 'keharusan menang' bukan berasal dari aturan institusi tertentu, tetapi karena laki-laki itu sendiri yang menginginkannya. Menurut Nenek, keinginan laki-laki tersebut harus dipenuhi. Perempuan, walau mungkin dia yang benar, harus tetap kalah. Secara tidak langsung, gagasan Nenek menempatkan lakilaki lebih tinggi daripada perempuan.

Posisi lebih tinggi ini tidak memandang kelebihan yang ada pada perempuan. Seberapa pun hebatnya seorang perempuan, ia akan tetap lebih rendah daripada laki-laki.

Teks menunjukkan hal ini dalam dialog Kejora dengan neneknya. Kejora menunjukkan raportnya yang menyebutkan ia meraih ranking satu, sedangkan adiknya, Prahara, tidak. Jawaban neneknya adalah "Ini kan nilai raport sekolahan, Cucu. Berapa pun nilai Prahara di sekolahan, sebagai laki-laki, ia tetap ranking pertama di dunia kenyataan. Sebaliknya kau. Berapa pun rankingmu, kau adalah perempuan dan akan tetap sebagai perempuan.” (62). Ungkapan sang nenek ini mengandung pemyataan bahwa laki-laki telah unggul sejak lahir dan merupakan 'bakat'nya yang 
tak akan pemah hilang sampai ia mati walaupun ada perempuan yang, misalnya, lebih segalanya darinya.

Keyakinan ini sesuai dengan pandangan sebagian penafsir kitab suci bahwa Hawa diciptakan dari rusuk Adam sehingga perempuan selalu menjadi nomor dua setelah laki-laki. Betapa pun luar biasanya seorang perernpuan, ia tetap tidak dapat menjadi nornor satu.

Gagasan ini ditentang keras oleh penutur, Kejora. la rnenjawab kata-kata neneknya di atas dengan: "'Tidak! Aku tidak rnau rnendengar katakatarnu, nenek jahat!' aku rnelengking histeris." (62). Kernudian, ia rnenentang prinsip neneknya ini dengan berbagai cara, yang terns ia lakukan hingga dewasa. Perlawanannya dapat dilihat dari berbagai aksinya dalarn rnenyikapi berbagai kondisi.

Aksi pertarna tokoh Kejora yang disuguhkan oleh teks dalarn rnewujudkan keseteraan gender adalah tekadnya untuk bersekolah tinggi dan rneraih prestasi. Ia ungkapkan tekadnya pada parnannya: “'Pada saatnya nanti,' kataku rnenirukannya, 'Parnanjuga akan tahu siapa aku, dan siapa di antara kita yang lebih berpendidikan" (85). Sarnpai pada bagian ini, bisa dilihat bahwa gagasan diungkapkan teks dengan cara Eksplisit tetapi tidak berkesan propaganda. Karena itu, berdasarkan kategori Williams, pengungkapan gagasan ini dapat dirnasukkan ke tipe kedua.

Selanjutnya, teks tidak rnernberikan cerarnah apa pun tentang berhaknya perernpuan rnenernpuh pendidikan setinggi-tingginya; teks rnengungkapkan gagasan tentang perlunya pendidikan bagi perernpuan rnelalui peristiwa, terutarna aksi-aksi tokoh-tokoh perernpuan dalarn novel ini. Bila dilihat dari kategori Williams, pengungkapan dengan cara ini dapat masuk ke tipe kedua atau kelirna. Tipe kedua adalah pengungkapan gagasan rnelalui berbagai unsur sastra, kadang rnuncul secara eksplisit, dan terlihat rnembujuk pernbaca untuk menerima gagasan tersebut. Dalam tipe kelima gagasan diungkapkan melalui penokohan tanpa ada pemyataan eksplisit danjauh dari kesan membujuk. Untuk mengetahui tepatnya gagasan ini masuk ke tipe mana, di bawah ini akan diberikan analisis peristiwa-peristiwa dalam novel yang mengandung gagasan ini.

Peristiwa pertama yang menunjukkan tekad Kejora untuk mencari ilmu adalah ulahnya menaiki pohon di halaman rumahnya yang dipagari tembok tinggi. Ayah Kejora, didukung Nenek, membentengi rumahnya dengan tembok tinggi dan melarang anak-anak perempuannya keluar rumah kecuali ke sekolah, sedangkan anak laki-laki boleh bermain di luar (75). la membatasi pengetahuan mereka; dengan tidak dapat pergi ke mana-mana, mereka tentu hanya mendapatkan pengetahuan seluas rumah dan halamannya. Anak-anak lakilaki dibolehkan bermain keluar pagar, yang tentu pengalamannya akan menambah pengetahuannya tentang hidup. Kejora dan kakaknya, Bianglala, melawan aturan ini dengan cara mengintip dari tembok atau menaiki pohon secara diamdiam. Mereka pun dapat memperluas cakrawala pengetahuan mereka (77).
Dari kutipan di atas dapat diduga bahwa maksud sang Ayah (dan Nenek) membentengi rumahnya adalah untuk membatasi anak-anak perempuan mempunyai pengetahuan yang lebih luas tentang kehidupan dunia. Dengan ilmu yang lebih tinggi, perempuan akan mempunyai kekuatan untuk mengalahkan laki-laki. Melihat kutipan di atas, penulis berpendapat bahwa gagasan yang disampaikan tampak tertulis secara eksplisit danjelas apa yang dimaksud, tetapi tidak bemada propaganda. Karenanya, cara pengungkapan gagasan ini merupakan tipe kedua dari tujuh tipe dalam kategori Williams.

Peristiwa kedua tentang kesetaraan pendidikan diambil dari alur cerita masa remaja Kejora, yaitu cerita tentang Kejora dan sahabatnya, Elya Huraibi. Banyak peristiwa yang dimunculkan di sini, tetapi masalah kesetaraan gender banyak terlihat dari penokohan Kejora dan sahabatnya. Kejora digambarkan sebagai tokoh yang punya tekad kuat. Tekad Kejora, selain terus mengejar ilmu, adalah berprestasi. Di sebuah pesantren putri tempat ia belajar setelah lulus dari sekolah dasar, ia termasukjajaran siswi yang cerdas, bahkan ia berhasil menjadi ketua majlis tahkim (sebuah majelis hukum untuk mengadili siswi-siswi yang melakukan kesalahan) saat dia kelas empat, sedangkan biasanya jabatan ketua dipegang siswa kelas lima atau enam. Dia adalah siswi terpandai di pesantrennya (103). Elya pun demikian, selain cerdas diajuga pandai berbicara dan tegas. Teks hendak menunjukkan bahwa perempuan pun mampu berprestasi. Gagasan tentang pentingnya pendidikan bagi perempuan dalam peristiwa ini tidak muncul secara eksplisit, tetapi maksud yang hendak disampaikan teks sangat jelas: Kejora mempunyai begitu banyak prestasi; yang berarti adalah perempuan harus pandai. Ditambah pula dengan kata-kata Kejora pada pamannya, yang di atas telah dikutip, yaitu: "Paman juga akan tahu siapa aku, dan siapa di antara kita yang lebih berpendidikan"” (85). Karena itu, dapat disimpulkan bahwa gagasan tentang pentingnya pendidikan bagi perempuan ini diungkapkan dengan tipe kedua: walau tidak eksplisit, gagasan muncul dengan kesan membujuk pembaca.

Peristiwa ketiga diberikan teks di awal cerita, yang termasuk dalam alur cerita masa dewasa Kejora. Novel dibuka dengan kepergian Kejora ke Marrakesh, Maroko, untuk mengikuti konferensi perempuan sedunia. Kejora bukan lagi dapat keluar rumah tetapi ia dapat ke luar negeri. Lagi pula, ia pergi bukan untuk bertamasya, tetapi mengikuti konferensi intemasional (1), yang tentu hanya dapat diikuti oleh orang-orang pandai. Di akhir novel, diceritakanjuga bahwa Kejora melanjutkan sekolah di sebuah perguruan tinggi di Damaskus (198). Dari bahasan ini, dapat disimpulkan bahwa penutur menuntut kesetaraan gender, dalam hal ini kesetaraan mengenyam pendidikan dan mendapatkan pengetahuan seluas-luasnya.

Dalam menarasikan cerita, banyak diselipkan nama-nama berbagai tempat di Timur Tengah berikut sejarahnya pada zaman nabi-nabi atau zaman kekhalifahan Islam. Contohnya adalah pe-nyebutan 
nama Mada in Shalih dan sejarahnya pada zaman Nabi Shalih, Cave Seven Sleepers dan sejarahnya mengenai Ashabul Kahfi (134-135), atau kisah-kisah ratu dari kerajaan Islam (64), atau uraian tentang kotakota seperti Marrakesh, Tangier, Cassablanca,dan Aleppo. Semuanya penulis lihat hendak menunjukkan betapa luasnya pengetahuan penutur yang sekaligus tokoh utama perempuan. Dua bahasan ini perginya Kejora ke konferensi perempuan intemasional dan luasnya pengetahuan yang ia miliki, makin memperjelas pengungkapan gagasan tentang pentingnya pendidikan bagi perempuan. Sama seperti cara dari bahasan sebelumnya, dengan gagasan yang tidak dimunculkan secara eksplisit, tetapi sangat jelas terlihat, cara pengungkapan ini masuk ke tipe kedua.

Gagasan ini didukung juga dengan penyebutan tokohtokoh perempuan lainnya yang merupakan perempuanperempuan cerdas. Yang pertama adalah teman Kejora yang mengundangnya ke Marrakesh: Nadia Masid. Uraian penutur tentang Nadia sangat persuasif(13). Nadia adalah perempuan muslim yang terpelajar, yang bersekolah hingga pendidikan tinggi, bukan perempuan yang hanya mengurusi pekerjaan domestik. Nadia juga diceritakan membaca buku Women and Sex dan The Hidden Face of Eve karya Nawal el Shadawi dan Beyond the Veil karya Fatima Memissi (13). Penyebutan karya - karya dari dua penulis besar berhaluan Feminis inijelas menunjukkan pemikiran tokoh Nadia. Penuturantentang tokoh Nadia jelas menunjukkan keberpihakan teks kepada perempuan. Tokoh kedua yang disebut adalah Fatima Mernissi, yang diceritakan sedang memberikan seminar (yang dihadiri oleh Nadia) tentang perempuan dan kekhalifahan (14). Penghargaan terhadap tokoh ini, yang adalah guru besar dari sebuah universitas terkemuka di Maroko, sudah menunjukkan keberpihakan teks pada perempuan terpelajar. Judul seminar dan uraian isi pembicaraan Mernissi dalam novel $G J$ ini makin menegaskan gagasan teks tentang kesetaraan perempuan dengan laki-laki.

Mengamati cara penyampaian gagasan kesetaraan ini, teks banyak mengungkapkannya melalui peristiwa, terutama aksi-aksi Kejora. Dari aksi-aksi tersebut, akan diperoleh gagasan yang diyakini tokoh ini. Hampir tidak ada pernyataan eksplisit tentang pentingnya pendidikan bagi perempuan,tetapi gagasan tersebut terlihat jelas dalam narasi. Disimpulkan bahwa gagasan mengenai kesetaraan pendidikan ini diperoleh dari analisis penokohan tokoh-tokoh perempuan dan alur.Melihat kategori pengungkapan gagasan yang diutarakan Raymond Williams, gagasanini termasuk tipe kedua, yaitu gagasan yang bertujuan membujuk pembaca tetapi dengancara yang lebih halus dari propaganda. Gagasan ini juga dekat dengan tipe kelima, yaitupengungkapan gagasan melalui penokohan; tetapi, dalam tipe kelima, gagasannya sangat tersembunyi sehingga tidak berkesan membujuk pembaca. Dalampengungkapan gagasan ini, teks tampak jelas menyampaikan misinya, yaitu perempuandapat menempuh pendidikan dengan kecerdasannya.

Tuntutan kesetaraan berikutnya adalah dalam mengkspresikan hasrat cinta. Ada sedikit penjelasan eksplisit tentang gagasan kedua halini, dan, kembali, aksi-aksi Kejoralah yang banyak mengungkapkan gagasan mengenai kesetaraan gender ini; lebih lagi, teks berkesan memberikan Kejora lebih banyak kemerdekaan daripada Zakky.

Terdapat satu peristiwa Kejora dengan agresif mencumbu Zakky (9). Satu peristiwa lagi diberikan hampir di akhir novel: "Atas pilihanku sendiri saat memasuki kamar Zakky, dan bukannya kamarku sendiri .... "(209). Peristiwa lainnya lagi adalah saat Kejora menginap di kamar adik perempuan Zakky di rumah orang tua Zakky sebelum acara lamaran, Kejora membolehkan Zakky mencium pipi dan bibirnya dengan menantangnya ketika ia mengetuk kamar tempat Kejora menginap: "Katakan saja ingin menciumku." (152).

Kutipan ketiga menunjukkan bahwa ciuman itu atas tantangan atau kehendak Kejora sendiri. Penutur mencoba menjelaskan hal ini dengan narasi "Kututup pintu dan menerangkan beberapa hal pada Najwa [adik Zakky] tentang yang dilihatnya." (152).Akan tetapi, tidak ada penjelasan apa pun tentang hal itu dalam narasi. Kutipan kedua dengantegas menyebutkan 'atas pilihanku sendiri' dan atas kehendakku sendiri', yang dapat langsung dipahami sebagai tuntutan kemerdekaan dari seorang perempuan: bahwa perempuan boleh melakukan apa saja yang ia kehendaki, tak ada yang memaksa atau melarang. Gagasan kemerdekaan perempuan pada kutipan pertama dijelaskan sepanjang satu paragraf setelahnya: "Jika laki-laki pandai menipu, perempuan tak kalah lihainya dalam hal menipu. Jika laki-laki senang berburu, tak ada salahnyaperempuan menyenangi hal yang sama." (9). Dua kalimat ini adalah tuntutan kesetaraan gender, bahwa laki-laki dan perempuan dapat melakukan hal yang sama. Kemerdekaan perempuan, menurut penutur, adalah kemerdekaan yang juga dimiliki makhluk lain dibumi. Dalam peristiwa ini, gagasan tentang perlu adanya kemerdekaan bagi perempuan terungkap secara eksplisit. Akan tetapi, pengungkapannya rnelalui peristiwa rnernbuatnyatidak seperti propaganda. Cara pengungkapan gagasan ini dikategorikan ke tipe kedua.

Terdapat satu peristiwa lagi yang rnenunjukkan agresivitas Kejora, yaitu saat ia merayu Asaav Muscovich dalarn rangka rnernbalas perlakuan Zakky padanya. Ia melihat Zakky sering mengajak Bianglala berbincang dan menatapnya dengan mesra, kemudian ia membalas dengan merayu Asaav dan beraksi lebih dari aksi Zakky: "Kupeluk lehernya Asaav dan kuurai rambutnya dengan kemesraan sempurna. Kuhambur segala sayang dan membisikinya dengan kata-kata puisi.” (187).

Permasalahannya, menurut penulis, adalah bahwa Kejora tidak memberikan kesempatan pada Zakky untuk bersikap agresif mencumbunya, yang dapat ditafsirkan bahwa teks bukan sekadar menuntut kesetaraan bagi perempuan, tetapidominasi perempuan terhadap laki-laki.

Hal tersebut dapat dilihat dalam dua peristiwa. Peristiwa pertama adalah saat mereka bertemu di Marrakesh dan Zakky memeluknya di dalam taksi. Kejora menolaknya dengan berkata, "Lepaskan, Zakky! Kau tidak berhak di sini. Ini negeri orang 
dan kita adalah tamu di sini. Jadi, harap dipelajari tata tertib." (4). Karena alasan sopan santun (tata tertib), ia menolak dicumbu. Peristiwa berikutnya adalah saat rnereka menginap di sebuah apartemen di Amman. Diceritakan bahwa Zakky memangku dan mendekap Kejora dari belakang dan ketika ia hendak menciumnya, Kejora menampar pipinya (132). la memberikan alasan penolakan itu dengan mengatakan bahwa ia menaati larangan dalam agama: "Pecutku ada di sini, dalam ingatanku. Kuambil dari salah satu ayat yang mengirimnya untuk kita. Walaa taqrabuz-zina. innahu kaana faakhisatan wa saa 'a sabiila, kata Alquran.” (132-133). Diceritakan pula bahwa dengan peringatan itu, Zakky tersadar dan cepat-cepat melepaskannya.

Seperti telah disebut di atas, penutur tampaknya tidak hanya menuntut kesetaraan, tetapi ia hendak menempatkan diri lebih tinggi dari posisi laki-laki. la bebas melakukan apa saja, sedangkan berkali-kali ia mengatur pacarnya. Sehubungan dengan masalah dominasi, Kejora punya teori sendiri:

"Dalam relasi laki-laki dan perempuan, tinggi rendahnya dominasi merupakan satu kondisi timbal balik yang tidak bersifat tetap. la bisa dipengaruhi oleh banyak faktor, terutama menurutku adalah faktor pendidikan. Menyusul kemudian faktor ekonomi, kelas sosial, agama dan lainnya. Bisa paham politik atau kecenderungan seni." (144)

Bila diamati lebih dalam, tokoh Zakky lebih unggul dalam beberapa faktor di atas: la sedang menjalani kuliah S2 sementara Kejora masih SMU; ayahnya lebih kaya dari ayah Kejora; kedudukannya lebih tinggi karena ayah Zakky adalah direktur sekolah Kejora. Faktor-faktor lain tidak disebut dalam novel. Akan tetapi, dalam mengekspresikan hasrat cinta, ditemukan bahwa dominasi bersifat tetap, yakni milik Kejora. Ada satu alasan yang diberikan Kejora untuk hal ini: kebebasan Zakky yang tanpa batas. Menurut Kejora, kebebasan Zakky absurd, sedangkan kebebasan dia berada di bawah pengawasan Tuhan (10). Akan tetapi, gagasan penutur tentang kebebasan yang tetap merasakan kehadiran Tuhan dalam hal mengekspresikan hasrat ini tidak jelas batasnya. Penutur membacakan ayat 'wa laa taqrobuz zina' (danjangan dekati zina), tetapi ia menoleransi ciuman bibir ketika ia menghendaki dan menolak ketika Zakky yang menghendaki. Kalaupun ciuman bibir tidak diartikan dekat dengan zina, Kejora tetap tidak adil.

Gagasan kemerdekaan perempuan dalam mengekspresikan hasrat cinta ini diperoleh dari sudut pandang. Semua sudut pandang tokoh utama dalam berpikir dan berkata mengenai hasrat cinta mengarah ke gagasan tersebut. Karena itu, penulis simpulkan bahwa cara pengungkapan gagasan ini termasuk dalam tipe kedua dari kategori Williams, yaitu cara pengungkapan gagasan yang cukup eksplisit dalam ucapan dan pikiran tokoh utama. Namun, aksi Kejora menunjukkan ia tidak sekadar menuntut kesetaraan gender, tetapi juga dominasi. Gagasan tentang dominasi tokoh perempuan ini tidak muncul secara eksplisit, penulis memperolehnya dari analisis penokohan. Karena itu, gagasan ini dikategorikan ke tipe kelima.

Gagasan ketiga dalam isu kesetaraan ini adalah bahwa apa yang dapat dilakukan seorang laki-laki dapat juga dilakukan seorang perempuan. Bila seorang lakilaki menyakiti perempuan, perempuan tersebut boleh membalas menyakitinya hendak menunjukkan bahwa perempuan tidak lemah dan tak bisa diperlakukan semena mena. Dengan kata lain, perempuanjuga dapat bertindak sebagai subjek, tidak melulu menjadi objek tindakan laki-laki.

Peristiwa yang menunjukkan hal ini muncul di setengah bagian terakhir novel, dan mengalir hingga bagian akhir novel saat solusi diberikan. Tokoh Kejora merasa Zakky, yang menurut teman-temannya sudah tobat dari perburuannya terhadap perempuan, tertarik pada Bianglala, kakaknya, yang biasa dipanggil Lola. Kejora sangat marah dan ia pun membalas sakit hatinya dengan mendekati Asaav dan merayunya. Kejora baru tahu kemudian mengapa Zakky sering mengobrol dengan Lola, yaitu karena Zakky hendak menjadi pembicara dalam sebuah seminar di kampus Lola. la pun memaafkan Zakky dan kembali padanya.

Pembalasan sakit hati atau upaya menunjukkan keberdayaan (sebagai lawan dari 'ketidakberdayaan') perempuan diungkapkan melalui aksi dan ucapan tokoh Kejora. Saat

Asaav mengunjungi apartemennya, Kejora dengan agresif mengajaknya menari Jahife (satujenis tarian Arab), duduk di pangkuannya, dan memeluknya. Semuanya ia lakukan untuk membalas Zakky. Alasan aksinya ini ia tumpahkan pada Zakky ketika ia kemudian datang dan menuduhnya pengkhianat: "Pengkhianat" Jika perempuan mengekspresikan kemerdekaannya disebut pengkhianat, lalu apa julukan bagi laki-laki yang bertindak serupa. Apa mereka disebut "penjahat aku menantang, menghadapi Zakky dengan kacak pinggang." (187-188). Beberapa hari berikutnya Zakky mengatakan bahwa kedatangan Asaav ini adalah atas idenya, tetapi tidak ada penjelasan apa maksud Zakky atas ide tersebut.

Ucapan Kejora di atas sudah cukup menjelaskan motivasi aksinya: ia menuntut kemerdekaan bagi perempuan. Dari ucapan tersebut dapat disimpulkan juga bahwa membalas perlakuan orang lain adalah upaya perempuan untuk memeroleh kemerdekaannya, dengan arti laki-laki tak dapat mengatur dan menekan perempuan di bawah kuasanya, karena perempuan pun punya inisiatif untuk melakukan hal yang sama dengan laki-laki. Penutur mengungkapkan ini secara eksplisit: "Tak ada lain, satu - satunya

cara membikinnya meledak adalah dengan memberinya pukulan yang sama. Jika kau dihantam, balas dengan menghantamnya. Jika kau dicium, balas menciumnya. Inilah hukum keadilan.” (200).

Dari peristiwa di atas, terungkap juga bahwa walaupun kedatangan Asaav adalah ideZakky, temyata Zakky diceritakan tidak mampu mengendalikan efek yang timbul: ia tidak kuasa meredam kemarahan Kejora. Disebutkan bahwa dengan sangat sedih ia 
berkata,"Kau telah membakarku habis, Jora. Tanpa sesuatu pun kulakukan. Kau telah membakarku habis!" Antara pilu dan marah yang teredam, ia berisak." (190). Kemudian ia merayu dengan berbagai pujian, tetapi Kejora tetap bergeming. Melalui peristiwa ini, teks mengungkapkan bahwa perempuan memiliki kuasa untuk mengekspresikan pendapatnya dan mempertahankan keputusannya.

Gagasan kemerdekaan perempuan dalam bertindak ini diungkapkan melalui aksi-aksi Kejora dan pemyataan-pemyataannya yang eksplisit, karenanya gagasan tersebut mudah ditangkap pembaca. Akan tetapi, ucapan-ucapan Kejora mengenai hal ini tidak berkesan menggurui pada pandangan penulis. Oleh karena itu, penulis mengategorikan pengungkapan gagasan ini ke tipe kedua.

Kesetaraan aksi juga dapat diketahui dari ucapan Kejora kepada adik Zakky ketika ia bertanya apa yang akan dilakukan Kejora bila Zakky poligami: "Aku akan poliandri, pakai cara-cara yang legal." "Seperti apa?" "Pertama mengkhulunya. Lalu menikah lagi dengan bintang film yang gantengnya melebihi Zakky. Poliandri atau tidak, yang penting kan rasa adilnya. Sama-sama dua." (151). Penutur menuntut kesetaraan antara laki-laki dan perempuan, tetapi dengan berusaha tetap bergerak dalam koridor agama.

Akan tetapi, sama dengan gagasan kesetaraan dalam mengekspresikan hasrat cinta dalam pembahasan sebelumnya, dengan mengamati alur cerita terlihat bahwa Kejora menang lagi karena Zakky tidak mampu sedetik pun menceritakan pembicaraannya dengan tokoh Lola, yang temyata adalah pembicaraan mengenai rencana seminar di kampus Lola. Kejora baru mengerti pada beberapa hari sebelum seminar, yang kemudian membuatnya berbaikan lagi dengan Zakky. Kejora berhasil mendominasi kasus ini dengan tidak memberikan kesempatan kepada Zakky untuk menflarifikasi masalah.

Gagasan keempat, yakni gagasan domiasi perempuan, ini penulis peroleh dari penokohantokoh perempuan, tidak ada pemyataan eksplisit tentang itu, maka penulis masukkan ke tipe kelima.

Dari kutipan di atas, juga didapatkan satu gagasan lagi seputar isu kesetaraan, yaitu tuntuan kesetaraan mempunyai lebih dari satu partner (suami/istri) yang berada di bawah aturan agama. Pengungkapan gagasan kelima ini diberikan melalui serangkaian peristiwa dan sedikit ungkapan eksplisit dari tokoh utamanya, yang membuat gagasan ini terlihat jelas dalam narasi, tetapi tidak propagandis. Karena itu,dapat disimpulkan bahwa gagasan ini diungkapkan dengan tipe kedua dari kategori Williams.

Ada satu peristiwa yang diberikan teks yang menunjukkan cara dua tokoh utama ini mendapatkan kesetaraannya. Ketika Zakky cemburu pada Asaav, ia memaksa Kejora untuk pulang ke Indonesia untuk menemui ayah Kejora dalam rangka melamamya. Kejora menurut walau pun dengan sangat terpaksa, karena diceritakan bahwa Kejora selalu ketus padanya selama perjalanan pulang. Ketika ditanya mengapa ia tidak menolak untuk pulang, ia menjawab bahwa ia tak dapat berbicara dengan orang yang waras (164). Peristiwa ini menunjukkan bahwa Kejora juga dapat mengalah, walau dengan terpaksa. Maka, keseteraan dapat tercapai karena laki-laki atau pun perempuan dapat/boleh mengekspresikan keinginan masingmasing.

Bila dikaitkan dengan kategori Williams, gagasan keenam ini tampak terungkap melalui analisis penokohan Kejora dan Zakky. Tidak ada pernyataan eksplisit tentang hal ini; setelah aksi kedua tokoh ini diteliti dengan hati-hati, barulah didapatkan hal itu. Karenanya, disimpulkan bahwa gagasan ini diungkapkan dengancara kelima kategori Williams.

Dari alur cerita tentang Kejora dan Zakky, muncul gagasan ketujuh, yaitu gagasan tentang kekuatan perempuan. Diceritakan bahwa Zakky berhenti dari perburuannya mengejar perempuan-perempuan cantik untuk dipacari setelah bertemu Kejora. Zakky yang tampan dan cerdas dan digilai banyak perempuan ini sangat memuja Kejora. Hal ini tentu menaikkan posisi Kejora karena ia dikejar oleh seorang pemuda yang banyak dikejar perempuan (200). Dengan menempatkan tokoh utamanya sebagai 'penakluk' sang 'penakluk perempuan', teks seakan hendak mengatakan bahwa seorang perempuan juga punya kekuatan besar untuk membuat seorang laki-laki hebat menyerah padanya. Secara sederhana dapat dikatakan bahwa teks hendak mengungkapkan kesetaraan laki-Iaki dan perempuan dalam memeroleh cinta dari lawan jenis.

Gagasan ini tidak pemah dimunculkan melalui pemyataan eksplisit, penulis memerolehnya melalui analisis tokoh; selain itu, tidak gagasan ini terlihat langsung saat pertama kita membaca, karena itu, dapat disimpulkan bahwa gagasan ini masuk tipe kelima dari kategori Williarns, yaitu tipe gagasan yang diungkapkan melalui analisis penokohan.

\section{SIMPULAN}

Dari uraian di atas, dapat dilihat bahwa dari sembilan gagasan dalam isu yang sama, empat gagasan masuk tipe kedua kategori Raymond Williams dan lima gagasan masuk ke tipekelima. Penggunaan dua tipe ini dapat menunjukkan bahwa novel mampu mengungkapkan gagasan tentang ketidakadilan gender dengan halus, tidak mempropaganda. Kemudian, suara penutur dilihat dari sudut pandang (pernyataan dan pemikiran) dan aksinya memiliki keberpihakan yang sama dengan peristiwa dan susunan peristiwa dalam teks, yaitu berpihak pada tokoh perempuan. Namun,ada dua gagasan yang menuntut posisi lebih tinggi bagi perempuan. Dua gagasan yangberbeda dengan tema utama yakni pengungkapan ketidak adilan gender ini diungkapkan dengan tipekelima, yaitu pengungkapan gagasan yang tersembunyi dalam penokohan. Karena itu, disimpulkan bahwa teks hendak mengungkapkan gagasan-gagasan mengenai kesetaraan gender, tetapi tanpa disengaja atau bahkan mungkin disengaja, terselip/diselipkan gagasan tentang dominasi perempuan terhadap laki-laki, sehingga dapat dikatakan bahwa teks sangat berpihak pada perempuan. 


\section{DAFTAR PUSTAKA}

Chatman, Seymour. 1978. Story and Discourse: Narrative Structure in Fiction and Film. New York: Cornell Unversity Press.

Damono, Sapardi Djoko. 2002. Pedoman Penelitian Sosiologi Sastra. Jakarta: Pusat Bahasa Departemen Pendidikan Nasional.

El Khalieqy, Abidah. 2004. Gent Jora. Yogyakarta: Matahari.

Engineer, Asghar Ali. 2001. "Islam, Women and Gender Justice”. Dalam Islamic Millenium Journal
Vol. II No. 1/Sept-Nov 2001. Jakarta: Asian Muslim Action Network-Indonesia dan Islamic Millenium Forum.

Menissi, Fatimah.1997. Beyond The Veil, Seks dan Kekuasaan. Terj. Masyhur Abadi. Surabaya:AI Fikr.

Rahman, Anita. 2005. "Women in the Family: Reinterpretation by Muslim Feminists". Dalam Indonesian Women in a Changing Society (ed. Kristi Poerwandari). Seoul: Ewha Women Univ. Press. 